\title{
An Approach in Medical Biophysics Learning Style Using Problem-Based Learning Method
}

\author{
Ismail Hegaze ${ }^{1}$,Everard von Kemenade ${ }^{2}$,Maryka von Duure ${ }^{3}$,Dalaia $\mathrm{Ali}^{4}$, Hala \\ Moustafa $^{5}$, Zineb Elfaramawy ${ }^{6}$ \\ Biochemistry, Biophysics Faculty of Applied Medical Science, Quality Assurance and Accreditation Center \\ ,October Six University (1,4,5).Fontys University of Applied Sciences (2,3), El Gad International Colleges for \\ Applied Medical Sciences(6)
}

\begin{abstract}
The motivation in implementing problem-based learning $(P B L)$ in medical biophysics education was started since 2011-2012. Hence it is better for the students to learn e.g medical biophysics using hands-on method. This paper will discuss the implementation of PBL in medical medical biophysics and student perception on the learning method. The study was performed on faculty of applied medical sciences students taking medical biophysics subject in the second semester in a University in Egypt. They were learned the physics topics for some weeks as a part of their learning method. The test on the perception of the students was carried out by distributing questionnaire at the end of PBL session. Problem-based learning (PBL) helps students develop their knowledge and understanding skills. Also their intellectual skills in integrating the principles and concepts of medical biophysics. Students acquire professional and practical skills in practicing the leader ship role and applying the principles of scientific research.Teaching content through skills is one of the primary distinguishing features of PBL with conventional method. In PBL, the students are more inductive. The results were analyzed using SPSS software. The problem-based learning of medical biophysics were successfully implemented to the students. From the facilitator observation generally the students were starting to understand the concept of PBL. They are also trained to be punctual, actively generating ideas in group and good motivator to the friends. $70 \%$ of students agree the relevancy of teaching and learning $(T \& L)$ method using PBL in medical biophysics syllabus and $90 \%$ of the students agree get useful benefits from the PBL methods.
\end{abstract}

Key words: PBL, Medical Biophysics, Teaching and learning

\section{Introduction:}

Problem solving is a critical aspect of professional practice [1]. Professionals must be able to interpret ambiguous, novel and conflicting situations that they regularly face in their work [2].Many new schools have adopted PBL at inception while several established schools have transited from the traditional lecture (teacher)based curriculum to the PBL learning students based curriculum[3]. Problem-based learning, Active Learning $(\mathrm{AL})$ and Student-Centered Learning [SCL] are all used in the literature to indicate the shift of emphasis Student centered teaching's dependence on group effectiveness may lie at the heart of the difficulty for researchers to prove that student centered teaching improves learning[4].Traditional lecture or textbook generated learning is at the core of education from elementary school through many graduate level programs in Egypt. These habits, however, differ from student to student. Some may try to take control of the group, others will become passive, and still others will become overly verbose, while others will shy away from commenting [5]. Observers of student group interaction often find that students do not work productively, waste time, repeat old information, or become confrontational.Regardless of the problem posed to a group of students; learning is proportional to the ability of that group to work effectively together. If teamwork is adequately guided by the instructor, the team also becomes a space for developing skills such as communication, leadership, team working and punctuality [6]. In September 2001 the Physics Education Research Group engaged in collaborative action research in order to design, implement and evaluate a Problem-based Learning first year physics course [7].

\section{Materials and Methods:}

The process of problem-based learning (PBL) is summarized graphically as in (Table.1). During each small group session, the student group will identify and prioritize a number of learning issues. Student independently study outside the small group to research new information and concepts. As part, lecturer acts as a facilitator for reference or discussing problem that arise during the PBL session . 
Table :(1).Shows the processes in PBL medical biophysics implemented to students in faculty of applied medical sciences

\begin{tabular}{|c|c|c|}
\hline Problem Based Learning & & Guide for tutors \\
\hline $\begin{array}{l}\text { Phases in the "Seven } \\
\text { Jump" }\end{array}$ & Specific functions of this phase & Activities of the tutor during this phase \\
\hline $\begin{array}{l}\text { 1. Clarify terms and } \\
\text { notions which are } \\
\text { unknown. }\end{array}$ & $\begin{array}{l}\text { 1. Make sure the problem has been } \\
\text { understood by all group members. }\end{array}$ & $\begin{array}{l}\text { 1. If necessary briefly explain the unknown terms or } \\
\text { concepts. }\end{array}$ \\
\hline $\begin{array}{l}\text { 2. Define the phenomena } \\
\text { or events to be explained. }\end{array}$ & $\begin{array}{l}\text { 2. All phenomena/events have to appear } \\
\text { in the various problem-definitions }\end{array}$ & $\begin{array}{l}\text { 2. If necessary, support the formulation of the } \\
\text { problem(s) with paraphrases and short summaries. }\end{array}$ \\
\hline $\begin{array}{l}\text { 3. Analyse the problem }(s) \text {. } \\
\text { Make a brief inventory of } \\
\text { everyone's first thoughts } \\
\text { which may explain the } \\
\text { phenomena/events. The } \\
\text { technique of brainstorming } \\
\text { might be useful. }\end{array}$ & $\begin{array}{l}\text { 3. First exploration of ideas, activation of } \\
\text { prior knowledge }\end{array}$ & $\begin{array}{l}\text { 3. Invite students non-verbally to have their say. } \\
\text { Take care that ideas are not waved aside. }\end{array}$ \\
\hline $\begin{array}{l}\text { 4. Cluster related ideas, } \\
\text { investigate systematically } \\
\text { deeper thoughts, } \\
\text { explanations for the } \\
\text { phenomenalevents. }\end{array}$ & $\begin{array}{l}\text { 4. Organize prior knowledge } \\
\text { Elaborate on groups members knowledge } \\
\text { structure. } \\
\text { Try to establish a first organization of a } \\
\text { new knowledge structure. } \\
\text { Become aware of gaps, conflicting ideas, } \\
\text { etc. in knowledge base. } \\
\text { Get a feeling for misconceptions }\end{array}$ & $\begin{array}{l}\text { 4. Paraphrase ideas which were expressed with } \\
\text { difficulty. } \\
\text { If necessary summarize. } \\
\text { Stimulate conflicting ideas, } \\
\text { Ask questions which probes students' thinking, ask } \\
\text { for consequences, alternatives, probe the tenability } \\
\text { of statements }\end{array}$ \\
\hline $\begin{array}{l}\text { 5. Formulate learning } \\
\text { goals. Agree with your } \\
\text { group about what you are } \\
\text { going to study: determine } \\
\text { what you do not know of } \\
\text { vaguely know, what } \\
\text { contradictory ideas were, } \\
\text { etc. Formulate questions } \\
\text { which are the basis of } \\
\text { what you intend to } \\
\text { investigate during the } \\
\text { period of self-study. }\end{array}$ & 5. Ownership of learning & $\begin{array}{l}\text { 5. Are the learning goals in line with what is } \\
\text { discussed before. } \\
\text { Broaden learning goals and stimulate students to } \\
\text { study them in-depth. }\end{array}$ \\
\hline $\begin{array}{l}\text { 6. Self-study. } \\
\text { Find additional } \\
\text { information outside the } \\
\text { group. Consult sources } \\
\text { such as books, journals, } \\
\text { videoproductions, } \\
\text { computerprograms, etc. }\end{array}$ & $\begin{array}{l}\text { 6. Confrontation with external resources. } \\
\text { Expanding, structuring, restructuring and } \\
\text { refining ones knowledge base. } \\
\text { Reflecting on what ones knows and what } \\
\text { is difficult to understand. }\end{array}$ & 6. Refer to qualitative good resources \\
\hline $\begin{array}{l}\text { 7. Synthesize and test the } \\
\text { information. } \\
\text { Report: discuss your } \\
\text { findings, try to separate } \\
\text { main and side-issues, } \\
\text { structure your knowledge. } \\
\text { Apply the acquired } \\
\text { knowledge to the original } \\
\text { phenomena / events } \\
\text { (the problem) in order to } \\
\text { check if you are now more } \\
\text { capable of } \\
\text { understanding/solving the } \\
\text { problem }\end{array}$ & $\begin{array}{l}\text { 7. Reorganization /restructuring of } \\
\text { knowledge. } \\
\text { Application of knowledge. } \\
\text { Critical appraisal of information } \\
\text { Self- assessment }\end{array}$ & $\begin{array}{l}\text { 7. (Press for) summaries, linking ideas together. } \\
\text { Distinguish main and side issues. } \\
\text { Ask questions. } \\
\text { Visualize what has previously been discussed: use } \\
\text { of blackboard, use metaphors, analogies, examples. } \\
\text { Ask for application of knowledge, provide } \\
\text { variations of the problem offered. } \\
\text { Clarify difficulties in the material. } \\
\text { Do not avoid explanations but use them sparingly. } \\
\text { Press for a critical consideration of the material } \\
\text { studied. } \\
\text { Identify gaps in knowledge and understanding; } \\
\text { make students aware of these gaps. } \\
\text { Stimulate group members to reflect on the progress } \\
\text { of their learning processes. }\end{array}$ \\
\hline
\end{tabular}

\section{Sample (Students):}

A total of 100 students were selected from medical biophysics \&biochemistry classes taught in the Faculty of Applied medical Science, October 6 University, Giza, Egypt. They were taking medical biophysics in the second semester 2012/2013.They were divided into groups containing ten members for each group. The students are allocated four weeks for the PBL session. During this session the students will work in their group to solve the real world problem. 
Case design:

One case segmentation schemes was examined: long and short. Figure (1) shows the real world problem as well the problem for the students to solve based on their skill and knowledge.

\section{CASE:}

Is a member in a small family living in a small town in Lower Egypt. He is 38 y old diabetic person. He was complaining of a painful swelling in the palm of his right hand. About 4 days ago he was clearing brush behind the barn and pricked his hand on a thorn. The thorn entered about 1 and half inches. He was bleeding he went to the hospital to see a doctor told him that he must undergo wound healing by laser.

\section{Figure (1): Real world problem for PBL session.}

\section{Environment}

Refers to situations that can occur when developing the activity in respect to the level of comprehension reached or used by the student, such as the possible strategies through which the problem can be solved, and the levels at which the problem is expected to be understood by the students.

\section{Curriculum}

The contents on which the activity is centered and for which it is basically created. The curriculum is the traditional of learning; however, in a problem-solving activity it must be subordinated to other elements.

\section{Analytic point of reference}

Refers to previous (retrospective) and future (prospective) contents and objectives of the courses integrated, with the purpose of refocusing and enriching the problem in order to foment a long-term retention and to stimulate the building of new questions by the students.

\section{Use of technology}

The technological elements (laboratory, and internet,) are involved in the problem-solving activity. One of the tasks students must cope with by using technology for solving problems is the identification and assessment of its plausibility, its significance and the role it plays in the process of solving the problem.

\section{Development of formative objectives}

This dimension deals with the statement in which abilities, attitudes and values are involved or promoted by the problem-solving activity. The instruments used to determine acquire information and student feedback on their perception of PBL. It is a quantitative approach where questionnaires were given to each student.

\section{The Course Experience Questionnaire (CEQ)}

Biophysics and biochemistry are an interdisciplinary science that applies the theories and methods of basic sciences to solve biological problems. The (CED) instrument was designed to measure differences in the quality of teaching between comparable academic organizational units in those important aspects of teaching about which students have direct experience and are therefore validly able to comment (quality of teaching, clear goals and standards, workload, assessment, emphasis on independence).

\section{The Course Experience Questionnaire (CEQ) :}

\begin{tabular}{|c|c|c|c|c|c|}
\hline Statement & $\begin{array}{c}\text { strongly } \\
\text { disagree } \\
1 \\
\end{array}$ & $\begin{array}{l}\text { Disagree } \\
2\end{array}$ & $\begin{array}{c}\text { Neutral } \\
3\end{array}$ & $\begin{array}{c}\text { Agree } \\
4\end{array}$ & $\begin{array}{c}\text { strongly } \\
\text { agree } \\
5\end{array}$ \\
\hline $\begin{array}{l}\text { 1-It's always easy here to know the standard of work } \\
\text { expected. }\end{array}$ & & & & & \\
\hline $\begin{array}{l}\text { 2- This course has helped me to develop my problem } \\
\text { solving skills. }\end{array}$ & & & & & \\
\hline $\begin{array}{l}\text { 3- There are few opportunities to choose the particular } \\
\text { areas you want to study. }\end{array}$ & & & & & \\
\hline $\begin{array}{l}\text { 4- The teaching staff of this course motivate students to do } \\
\text { their best work. }\end{array}$ & & & & & \\
\hline 5- The workload is too heavy. & & & & & \\
\hline 6- This course has sharpened my analytical skills. & & & & & \\
\hline $\begin{array}{l}\text { 7- Lecturers her frequently give the impression they have } \\
\text { nothing to learn from students. }\end{array}$ & & & & & \\
\hline $\begin{array}{l}\text { 8- To do will in this course all you really needed was a } \\
\text { good memory. }\end{array}$ & & & & & \\
\hline
\end{tabular}




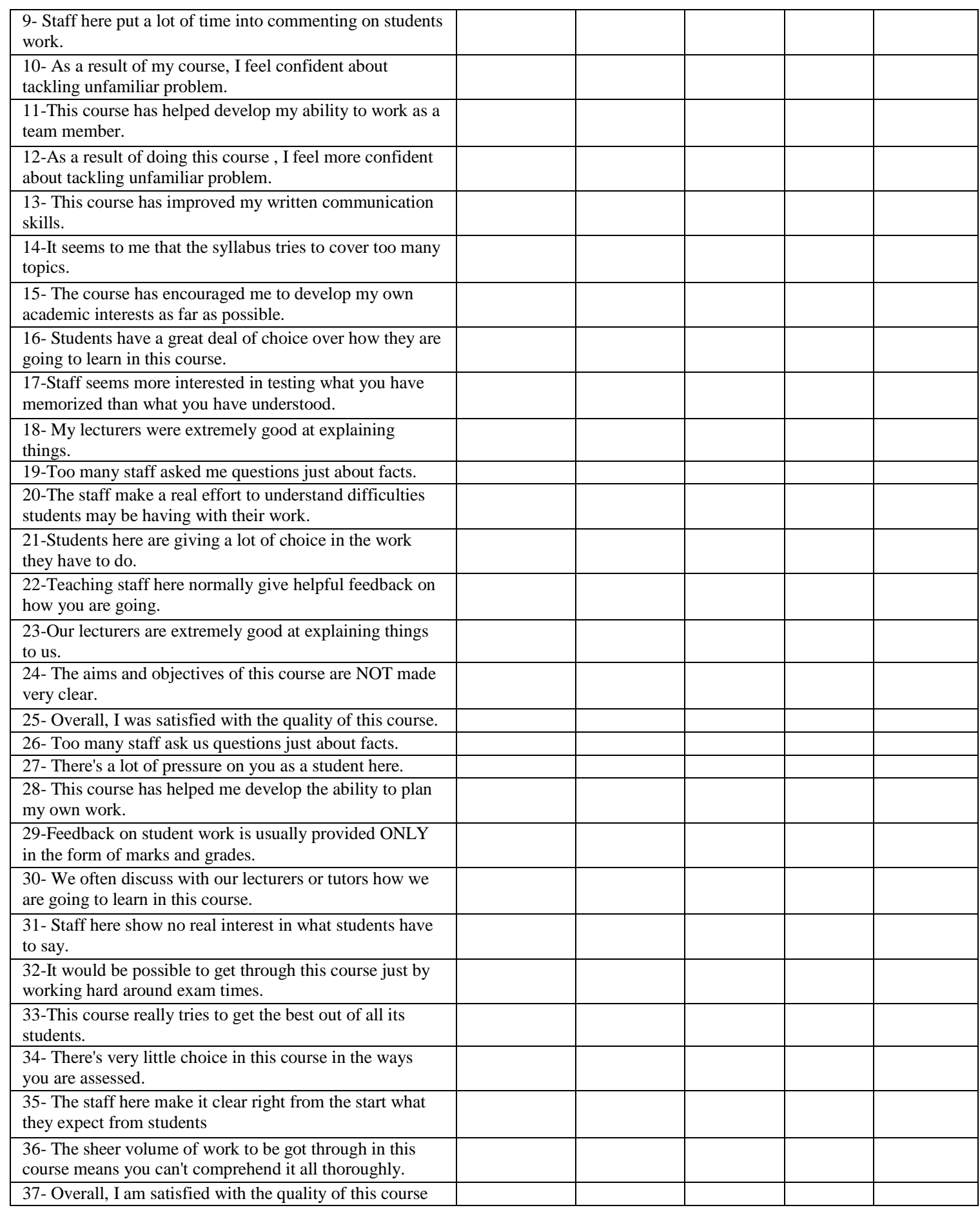

\section{Results and discussion:}

The questionnaires contain three sections consisting thirty seven items .

\section{The first section :}

The first section is about The Relevancy of Teaching and Learning ( $\&$ \& $\mathrm{L}$ ) Method Using PBL in medical biophysics Syllabus. Based on the finding, $70 \%$ of the students on the whole agree with the PBL method and viewed PBL positively. The students like to learn medical biophysics using the PBL method. They found it is easier to understand medical biophysics when using the PBL than the conventional method in the class. In addition they are able to finish the PBL in the time given. 
The second section:

The students were asked on their method to solve the medical biophysics problem using PBL method. To solve the problem, $80 \%$ are agreeing use the methods as follows:

(i)Doing some references from books and journals related to PBL.

(ii) Searching information from internet.

(iii)Referring to lecture notes.

(iv)Doing simple experiment to study/ solve the PBL problem.

\section{The third section:}

The students were asked the benefit they get from the PBL method. It is found that $90 \%$ of the students agree get useful benefits from the PBL methods as follow:

(i)The relationship among friends becomes better.

(ii)Improve understanding in medical biophysics.

(iii)Improve leadership skill.

(iv)Improve in communication style.

(v)More confident when were asked about topics in medical biophysics .

(vi)Learn new knowledge out of medicalbiophysics syllabus as well new experiences.

(vii)Learn to solve problems in more systematic ways.

Table (2): Mean score interpretation

\begin{tabular}{|l|l|}
\hline Mean Score & Scale Interpretation \\
\hline $5 \%$ & strongly disagree \\
\hline $10 \%$ & disagree \\
\hline $5 \%$ & neutral \\
\hline $10 \%$ & agree \\
\hline $70 \%$ & strongly agree \\
\hline
\end{tabular}

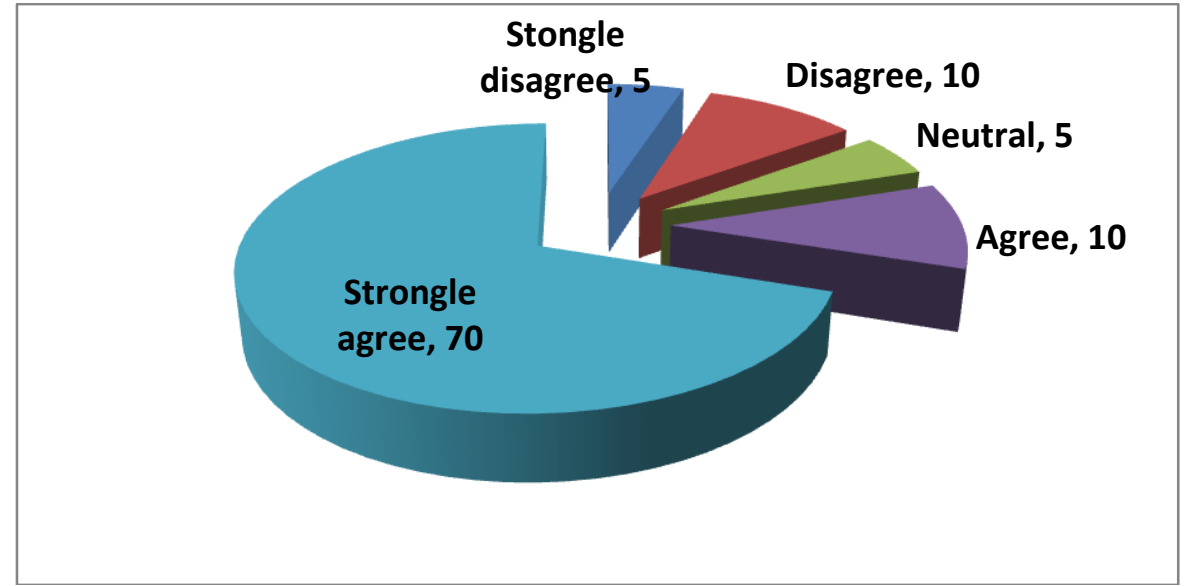

Figure (2): Graph showing the mean score interpretation

\section{Conclusion:}

The problem-based learning of medical biophysics were successfully implemented to the students. From the facilitator observation generally the students were starting to understand the concept of PBL. They are also trained to be punctual, actively generating ideas in group and to be good motivator to the friends.70\% of students agree the relevancy of teaching and learning ( $T \& L$ ) method using PBL in medical biophysics syllabus and even $90 \%$ of the students agree they get useful benefits from the PBL methods. These results are in agreement with previous studies and in line with the findings derived from problem based learning studies, [910-11-12].

\section{Acknowledgements:}

I wish to thank the Fontys University of Applied medical sciences staff, who were involved in the development and implementation of the Problem-based Learning course; Prof.Dr Maryka Duure, Prof.Dr.Ismail Hegaze and also the faculty Board for supporting the development of the Problem-based Learning course 


\section{References:}

[1]. Bereiter C, Scardamalia M. Surpassing ourselves: an inquiry into the nature and implications of expertise.Chicago: Open Court, 1993.

[2]. Schön DA. Educating the Reflective Practitioner. San Francisco: Jossey-Bass, 1987.

[3]. Achike, F. I. and Nain, N., 2005 "Promoting problem-based learning (PBL) in nursing education: A Malaysian experience", Nurse Education in Practice 5, 302-311, Elsevier Ltd.

[4]. Mihyar Hesson and Kaneez Fatima Shad, A Student-Centered learning Model, American Journal of Applied Sciences 4 (9): 628636, 2007.

[5]. Berhannudin Mohd Salleh (2007), Adopting Problem-based Learning in the Teaching of Engineering Undergraduates: A Malaysian Experience, Proceedings of International Conference on Engineering Education - ICEE 2007, September 3-7 2007, Coimbra Portugal.

[6]. Ahmad Hadi Ali and Siti Nur Kamariah Rubani, Problem-Based Learning in Physics Education: A Study on Engineering Students, Proceedings of Seminar Kebangsaan Aplikasi Sains dan Matematik 2008 (SKASM2008), Johor Malaysia, 24-25 November 2008

[7]. Bowe, B. and Cowan, J. (2004) "Physics: A Lecture-based Course and a Problem-based Course: A Comparative Evaluation of Problem-based Learning," in M. Savin-Baden, M.and K. Wilkie (eds.) Challenging Research into Problem-based Learning. Buckingham:SRHE/Open University Press.

[8]. Neville AJ. Problem-based learning and medical education forty years on: a review of its effects on knowledge and clinical performance. Med Princ Pract 2009; 18:1-9. Epub 2008 Dec 4.

[9]. L.P. Samaranayake. (2013) Problem-based learning. The HinduToday's. Published: October 7, 2013 00:00 IST | Updated: October 7, 2013 02:01 IST October 7, 2013.

[10]. Ahmed Yaqinuddin. (2013). Problem-Based Learning as an Instructional Method . Journal of the College of Physicians and Surgeons Pakistan 2013, Vol. 23 (1): 83-85

[11]. Rodrigo Polanco, Patricia Calderón and Francisco Delgado, (2004), Effects of a problem-based learning program on engineering students' academic achievements in a Mexican university, Innovations in Education and Teaching International Vol. 41, No. 2, May 2004.

[12]. Moustafa,H,et al.,(2012) Assessing Problem-Based Learning: A Case Study of a Medically Oriented Biophysics Problem-Based Learning Course J Am Sci 2012;8(12):725-728]. 